\title{
Hospital Readmissions Due to Subcapsular Renal Hematoma After Flexible and Rigid Ureterorenoscopy
}

\author{
Fleksibl ve Rijid Üreterorenoskopi Sonrası Görülen Subkapsüler Hematom Nedeniyle \\ Hastaneye Yatışların Karşılaştııı Iması
}

\author{
(D) Kerem Taken ${ }^{1}$, (D) Mustafa Güneş ${ }^{1}$, (D) Müslüm Ergün², (D) Muhammet İrfan Dönmez ${ }^{3}$ \\ ${ }^{1}$ Van Yüzüncü Yıl University Faculty of Medicine, Department of Urology, Van, Turkiye \\ ${ }^{2}$ Muş State Hospital, Clinic of Urology, Muş, Turkiye \\ ${ }^{3}$ Konya Training and Research Hospital, Clinic of Pediatric Urology, Konya, Turkiye
}

\section{What's known on the subject? and What does the study add?}

The literature regarding subcapsular hematoma after ureterorenoscopy is scarce. To our knowledge, this is the first study that compares flexible vs rigid ureterorenoscopy techniques. Our results indicate hospitalization rates due to subcapsular hematoma after ureterorenoscopy is statistically not different between two groups.

\begin{abstract}
Objective: The aim of this study is to compare the rates of hospitalization due to subcapsular renal hematoma (SRH) following flexible ureterorenoscopy (FURS) and semirigid ureterorenoscopy (RURS) for the treatment of ureteral and renal stones.

Materials and Methods: Patients who have been treated with FURS and RURS at two different institutions between March 2009 and February 2014 were enrolled in the study. Patient files and hospital records were reviewed. Pneumatic lithotriptor was used in RURS while holmium:yttrium aluminium garnet laser was used for FURS. Subcapsular hematoma diagnosis was based on clinical and radiological findings. Comparative analysis of patients with SRH in terms of age, sex, stone size/position, degree of preoperative hydronephrosis, duration of surgery and size of hematoma was done.

Results: A total of 1187 patients were found to have undergone ureteroscopic intervention due to ureteal or renal stones. RURS was performed in 992 (83.6\%) patients and FURS was performed in 195 patients (16.4\%). Of the 992 patients who underwent RURS, postoperative SRH occurred in 6 patients (0.6\%). Postoperative SRH occurred in 3 patients (1.5\%) who underwent FURS. Of the 9 patients who developed SRH, blood transfusions were needed in three patients and one patient was treated with percutaneous drainage catheter insertion. No patient underwent open surgery. There was no statistically significant difference between the two types of surgeries with regard to age, stone size/localization, degree of preoperative hydronephrosis, duration of surgery and size of SRH ( $p>0.05$ ).
\end{abstract}

Conclusion: SRH is a rare complication following RURS and FURS. There is no statistically significant difference in the risk for this specific complication between FURS and RURS.

Keywords: Subcapsular hematoma, Ureterorenoscopy, Complication, Rigid, Flexible

Öz

Amaç: Bu çalışmanın amacı üreter ve böbrek taşlarının endoskopik tedavisinde fleksibl ve rijid üreterorenoskopi sonrası ortaya çıkan subkapsüler hematom olgularının hastaneye yatışlarını karşılaştırmaktır.

Gereç ve Yöntem: İki farklı hastanede Mart 2009 ve Şubat 2014 yılları arasında yapılmış olan fleksibl ve rijid üreterorenoskopi olguları retrospektif olarak tarandı. Hasta dosyaları ve hastane kayıtları incelendi. Rijid üreterorenoskopi için pnömotik, fleksibl üreterorenoskopi için holmium lazer kullanıldı. Subkapsüler hematom tanısı klinik ve radyolojik olarak konuldu. Hastalar iki grup için de yaş, cinsiyet, taş boyutu ve yeri, işlem öncesi hidronefroz derecesi, operasyon süresi ve hematom boyutu açısından karşılaştırıldı.

Correspondence: Kerem Taken MD, Van Yüzüncü Yıl University Faculty of Medicine, Department of Urology, Van, Turkiye E-mail: takenyyu@yahoo.com ORCID-ID: orcid.org/0000-0002-4370-4222

Received: 21.03.2018 Accepted: 01.06.2018

Cite this article as: Taken K, Güneş M, Ergün M, Dönmez Mi. Hospital Readmissions Due to Subcapsular Renal Hematoma After Flexible and Rigid Ureterorenoscopy. J Urol Surg 2018;5(3):149-153.

- Copyright 2018 by the Association of Urological Surgery / Journal of Urological Surgery published by Galenos Publishing House. 
Bulgular: Toplamda 1187 hastanın üreterorenoskopik girişim geçirmiş olduğu bulundu. Rijid üreterorenoskopi 992 hastaya (\%83,6), fleksibl üreterorenoskopi ise 195 hastaya $(\% 16,6)$ uygulandı. Rijid üreterorenoskopi grubunda $6(\% 0,6)$, fleksibl üreterorenoskopi grubunda ise 3 hastada $(\% 1,5)$ işlem sonrası subkapsüler renal hematom geliştiği saptandı. Bu 9 hastanın üçünde kan transfüzyonu gerekirken, birinde de perkütan drenaj kateteri yerleştirilmesi gerekliliği oldu. Hiçbir hastada açık cerrahi gerekmedi. İki hasta grubunda belirtilen parametreler açısından hiçbir fark bulunamadı $(p>0,05)$.

Sonuç: Rijid ve fleksibl üreterorenoskopi sonrası görülebilen subkapsüler hematom nadir bir komplikasyondur. Bu komplikasyonun gelişme riski fleksibl ve rijid üreterorenoskopi gruplarında benzerdir.

Anahtar Kelimeler: Subkapsüler hematom, Üreterorenoskopi, Komplikasyon, Rijid, Fleksibl

\section{Introduction}

Ureteroscopic lithotripsy is a highly effective and minimally invasive procedure in the treatment of ureteric and renal stones (1). The increased benefit, efficacy, and success due to ureteroscopy and intra-corporal lithotripsy over time have been credited to the development of efficient and flexible ureteroscopes, laser lithotripters, and various other accessories. Flexible ureterorenoscopy (FURS) and laser lithotripsy has become increasingly popular in the treatment of large renal stones because of decreased morbidity rates and hospital stay, coupled with high stone-free rates that are similar to percutaneous nephrolithotomy (PCNL) $(2,3)$.

Subcapsular renal hematoma (SRH) is a rare complication that may follow urologic procedures such as shock wave lithotripsy, ureterorenoscopy, and PCNL $(4,5,6)$. The objective of this study was to compare hospitalization due to SRH following FURS and semirigid ureterorenoscopy (RURS) in the treatment of ureteral and renal stones.

\section{Materials and Methods}

Patients who were treated with FURS and RURS at two institutions between March 2009 and February 2014 were enrolled in the study. Patient files and hospital records were retrospectively reviewed after approval of the Yüzüncü Yıl University Ethics Committee (approval number: 2015-00/122), and provided written informed consent.

The endoscopic procedures were performed by one of 4 urologists using general anesthesia with the patients in the lithotomy position. A pneumatic lithotriptor was used in RURS and a holmium:yttrium aluminium garnet (Ho:YAG) laser was used for FURS. The diagnosis of ureteric and renal stones was made using intravenous pyelography or computed tomography (CT). For ureteroscopy, an 8.5/9.5 Fr semirigid ureteroscope (Richard Wolf $\mathrm{GmbH}$, Knittlinger, Germany) and a 6/8.8 Fr flexible ureteroscope (Richard Wolf GmbH, Knittlinger, Germany) were used. For lithotripsy, a pneumatic lithotripsy device (ElmedVibrolith, Ankara, Turkiye), and a Ho:YAG laser (Richard Wolf $\mathrm{GmbH}$, Knittlinger, Germany) with 270 and $365 \mu$ laser fibers were used. A safety guide wire was inserted for guidance of the rigid ureteroscope without dilating the ureteric orifice under fluoroscopy. For FURS, a $12 \mathrm{Fr}$ ureteral access sheath was used in all patients. Continuous irrigation was supplied from 1 meter above the level of the patient to obtain and sustain a clear operative visual field during all procedures. Moreover, manual hand pumps were used when continuous irrigation became insufficient. For laser lithotripsy, the laser energy was applied at $0.8-1.5 \mathrm{~J}$ with a pulse rate of $5-10 \mathrm{~Hz}$. The pneumotic lithotripter was used at 4-10 bar pressure with a pulse rate of $4-10 \mathrm{~Hz}$. Stone fragmentation was completed when a particle size of 2-3 $\mathrm{mm}$ was achieved. No effort was made to extract or remove stone fragments. After the procedure, an indwelling $4.7 \mathrm{Fr} 26 \mathrm{~cm} \mathrm{JJ}$ stent was placed and left in situ for 3 weeks when necessary. Kidney, ureter, and bladder imaging and ultrasonography were used during follow-up.

SRH was suspected in patients with side pain, fever, or hematuria following procedures and those patients were immediately evaluated by CT. Upon diagnosis of SRH, all patients were admitted to hospital. Appropriate analgesic and antibiotic therapies were initiated. A comparative analysis was conducted in patients with SRH in terms of age, sex, stone size/position, degree of preoperative hydronephrosis, duration of surgery, and size of hematoma.

\section{Statistical Analysis}

All data were analyzed using Statistical Package for the Social Sciences version 13.0 (SPSS Inc., Chicago, United States of America). Descriptive statistics for the continuous variables were presented as mean \pm standard deviation, and minimum and maximum values. The categorical variables were represented as absolute numbers and percentages. The Mann-Whitney $U$ test was used to compare RURS and FURS groups. In addition, Z-test and Fisher's exact test were performed to determine the differences between the two proportions. A $p$ value of $>0.05$ was considered significant.

\section{Results}

A total of 1187 patients were found to have undergone ureteroscopic intervention due to ureteal or renal stones. The patients comprised 804 (67.7\%) men and 383 (32.3\%) women with a mean age of $39 \pm 20.8$ years (range, $20-79$ years). RURS 
was performed in 992 (83.6\%) patients and FURS was performed in $195(16.4 \%)$. All patients with SRH presented with severe ipsilateral flank pain accompanied by other symptoms such as gross hematuria, fever, and abdominal pain. The patients were hospitalized for a week, antibiotherapy and analgesics were administered, and a complete blood count and follow-up was performed. Table 1 presents the clinical features and outcomes of the 9 patients who presented with SRH after ureteroscopy.

Of the 992 patients, who underwent RURS, 6 patients (5 males and 1 female) with a mean age of 36.3 years (range, 20-67 years) were hospitalized because of postoperative SRH (0.6\%). The mean stone size was $1.58 \mathrm{~cm}$ (range, $0.7-3.1 \mathrm{~cm}$ ). The stones were in the proximal $(n=2)$, mid $(n=2)$, and distal ureter $(n=1)$, and 1 was in the renal pelvis of the kidney. Preoperative ultrasonography revealed mild hydronephrosis in one patient, and three and two patients presented with moderate and severe hydroneohprosis, respectively. In the SRH group, two patients required manual pump irrigation and another two had a postoperative JJ stent inserted.

Among the 195 patients who underwent FURS, 3 patients (1.5\%) (3 men, 1 woman) with a mean age of 46.6 years (range, 24-79 years) were hospitalized after developing SRH. The mean stone size was $1.46 \mathrm{~cm}$ (range, $0.8-2.5 \mathrm{~cm}$ ). The stone was located in the proximal ureter in one patient, whereas the remaining two patients had lower caliceal stones. One of the patients presented with mild hydronephrosis; the other two had moderate hydronephrosis. Also, one patient had a JJ stent postoperatively and another was on anti-platelet therapy. Table 2 presents the comparative results of SRH for surgery types according to stone localizations. There was no statistically significant difference in length of hospital stay between patients undergoing FURS or RURS who developed SRH and those without SRH ( $p>0.05$ ). Table 3 presents the descriptive statistics and comparative results for surgery types. There was no statistically significant difference between the two types of surgery with regards to age, stone size/localization, degree of preoperative hydronephrosis, duration of surgery, and size of SRH ( $p>0.05)$.

Blood transfusion was needed in 3 patients, two of whom were in the RURS group. Only a woman aged 24 years, who presented with fever $\left(38.5^{\circ} \mathrm{C}\right)$ and a $9.5 \mathrm{~cm}$ SRH after RURS, needed percutaneous drainage. She was discharged after 1 week of close follow-up. No patient underwent open surgery or angioembolization because of SRH.

\section{Discussion}

The causes of SRH include renal trauma, tumors, vascular diseases, infections, renal cystic diseases, and bleeding disorders $(7,8,9)$. An incidence of lower than $0.4 \%$ has been reported

Table 2. Comparative results of subcapsular renal hematoma for surgery types according to stone locations

\begin{tabular}{llllll}
\hline Stone localization & RURS & SRH & FURS & SRH & p value $^{*}$ \\
\hline Kidney & 25 & 1 & 91 & 2 & 0.521 \\
Proximal ureter & 183 & 2 & 99 & 1 & 0.948 \\
Middle ureter & 245 & 2 & 4 & 0 & 0.156 \\
Distal ureter & 539 & 1 & 1 & 0 & --- \\
Total & 992 & 6 & 195 & 3 & 0.172 \\
\hline
\end{tabular}

RURS: Semirigid ureterorenoscopy, FURS: Flexible ureterorenoscopy, $\mathrm{SRH}$ : Subcapsular renal hematoma

${ }^{*} p<0.05$

Table 1. Clinical features and outcomes of the 9 patients with subcapsular renal hematoma

\begin{tabular}{|c|c|c|c|c|c|c|c|c|}
\hline & Age/sex & Procedure & $\begin{array}{l}\text { Stone } \\
\text { location }\end{array}$ & $\begin{array}{l}\text { Stone } \\
\text { size } \\
(\mathrm{mm})\end{array}$ & $\begin{array}{l}\text { Degree of } \\
\text { preoperative } \\
\text { hydronephrosis }\end{array}$ & $\begin{array}{l}\text { Duration of } \\
\text { operation } \\
\text { (mins) }\end{array}$ & $\begin{array}{l}\text { Size of } \\
\text { hematoma } \\
(\mathrm{cm})\end{array}$ & Treatment \\
\hline 1 & $45 / \mathrm{m}$ & RURS & Right, kidney & 18 & Moderate & 80 & 5 & Conservative \\
\hline 2 & $67 / \mathrm{m}$ & RURS & Left, proximal & 7 & Moderate & 40 & 3 & Conservative \\
\hline 3 & $23 / m$ & RURS & Left, proximal & 17 & Severe & 80 & 7 & Blood transfusion \\
\hline 4 & $39 / m$ & RURS & Right, middle & 31 & Severe & 70 & 5 & Conservative \\
\hline 5 & $20 / f$ & RURS & Left, middle & 12 & Mild & 30 & 4 & Conservative \\
\hline 6 & $24 / \mathrm{m}$ & RURS & Left, distal & 10 & Moderate & 40 & 9.5 & $\begin{array}{l}\text { Blood transfusion } \\
\text { and drainage }\end{array}$ \\
\hline 7 & $24 / f$ & FURS & Right, kidney & 11 & Mild & 48 & 3.5 & Conservative \\
\hline 8 & $79 / m$ & FURS & Left, kidney & 25 & Moderate & 60 & 4 & Blood transfusion \\
\hline 9 & $37 / \mathrm{m}$ & FURS & Right, proximal & 8 & Moderate & 35 & 3.5 & Conservative \\
\hline
\end{tabular}

RURS: Semirigid ureterorenoscopy, FURS: Flexible ureterorenoscopy, m: male, f: female 
Table 3. Descriptive statistics and comparative results for surgery types

\begin{tabular}{|c|c|c|c|c|}
\hline & & $n$ & Mean & p value* \\
\hline \multirow[t]{5}{*}{ Age } & RURS & 6 & 36.33 & 0.521 \\
\hline & FURS & 3 & 46.67 & \\
\hline & & & $(24-79)$ & \\
\hline & Total & 9 & 39.78 & \\
\hline & & & (20-79) & \\
\hline \multirow[t]{6}{*}{ Stone size } & RURS & 6 & 15.83 & 0.855 \\
\hline & & & $(7-31)$ & \\
\hline & FURS & 3 & 14.67 & \\
\hline & & & $(8-25)$ & \\
\hline & Total & 9 & 15.44 & \\
\hline & & & $(7-31)$ & \\
\hline \multirow[t]{6}{*}{ Duration of surgery } & RURS & 6 & 56.67 & 0.548 \\
\hline & & & $(30-80)$ & \\
\hline & FURS & 3 & 47.67 & \\
\hline & & & $(35-60)$ & \\
\hline & Total & 9 & 53.67 & \\
\hline & & & $(30-80)$ & \\
\hline \multirow[t]{5}{*}{ Size of hematoma } & RURS & 6 & 5.58 & 0.213 \\
\hline & & & $(3-10)$ & \\
\hline & FURS & 3 & $\begin{array}{l}3.67 \\
(3.5-5)\end{array}$ & \\
\hline & Total & 9 & 4.94 & \\
\hline & & & $(3-10)$ & \\
\hline
\end{tabular}

RURS: Semirigid ureterorenoscopy, FURS: Flexible ureterorenoscopy ${ }^{*} p<0.05$

following ureterorenoscopy $(5,8,10)$. Different mechanisms have been suggested for the development of SRH following ureteroscopy, including guide wire manipulation; fornix rupture secondary to high irrigation pressure; postoperative double-j stent placement; increased intrapelvic pressure in hydronephrotic kidneys, which results in tension, kinking and/ or obstruction in the main vascular structures; recanalization of ureters following ureteroscopy; and sudden expansion and rupture of the compressed parenchyma.

Previous authors have defined the risk factors as stone size, hydronephrosis degree, surgery duration, and irrigation fluid pressure $(4,5,10)$. Precautions such as using low pressure irrgiation during procedures are advised. These precautions may include ceasing fluid flow or ureteroscope removal, and placing a 8-10 $\mathrm{Fr}$ urethral catheter into the bladder during surgery in cases that are predicted to take a long time $(7,10)$. In a study by
Rehman et al. (11), it was demonstrated that use of a $12 / 14 \mathrm{Fr}$ access sheath could keep intrarenal pressure below $20 \mathrm{mmHg}$ during maximum irrigation flow. In our series, preoperative hydronephrosis, JJ stent placement, exposure to high intrapelvic pressure, and aspirin intake were factors that facilitated SRH. However, it is impossible to make a conclusion about the exact etiologic factors because there were too few patients in the study group.

The most common symptoms in patients with SRH include side pain, fever, hematuria, palpable mass, and bloodloss-related symptoms $(5,9)$. All of our patients had side pain and fever. The time interval between the initial surgery and the corrective operation varied between 3 and 7 days, which has been reported to be between the $10^{\text {th }}$ hour and $20^{\text {th }}$ day in the literature (10). Interestingly, with the exception of one patient, who presented with side pain and fever on the $20^{\text {th }}$ day, the mean time between surgery and the time of re-admittance in our study was 5.4 days.

Historically, Kendall et al. (12) proposed radical nephrectomy as a treatment when there is no apparent etiology and the contralateral kidney appears normal after careful pathologic examination, because of the high incidence of small renal tumors. Currently, it has been reported that operative exploration was not necessary in most unexplained cases because of the diagnostic accuracy of CT $(13,14,15)$. Chiu et al. (10) reported post-ureteroscopy SRH in $4(0.36 \%)$ out of 1114 patients. In their report, they documented that one patient underwent urgent angiography after a significant drop in the hemoglobin level, but no embolization was needed. Another patient underwent ultrasonography-guided drainage of the hematoma, and one had an emergency open clot evacuation because of significant compression on the kidney by the hematoma (10). Meng et al. (9) diagnosed $8(0.4 \%)$ of 1918 patients as having SRH after ureteroscopy. They managed five patients with small and uninfected hemorrhage conservatively, but reported that three patients with infective and large hemorrhage were managed using percutaneous nephrostomy $(n=1)$ and percutaneous subcapsular drainage $(n=2)$. Super-selective renal arterial embolization has also been reported in the literature for the treatment of SRH after flexible ureteroscopic laser lithotripsy (16).

All patients who present with symptomatic SRH should be hospitalized. The first-line treatment in patients with SRH should be conservative. This approach includes antibiotic treatment, pain control, and close follow-up of hemoglobin levels. Initial creatinine levels should also be monitored. In cases of hemodynamic deterioration, open surgery or percutaneous drainage of the hematoma are recommended rather than conservative treatment $(6,10,11)$. None of our patients required open surgical interventions or arterial embolization, but percutaneous drainage was performed in one patient because 
of a huge hematoma that was infected. Blood transfusion was needed in three patients. No residual hematoma was detected on $\mathrm{CT}$ scans at the $6^{\text {th }}$ month follow-up checks.

\section{Study Limitations}

There have been few studies to date that directly reported comparative analyses and outcomes of patients hospitalized with SRH after ureteroscopy. Our study was limited because of its retrospective nature and relatively small number of patients with SRH. Therefore, the statistical comparisons may be insufficient. However, our study showed that the risk of hospitalization because of SRH following RURS and FURS was comparable and low.

\section{Conclusion}

SRH is a rare complication that may follow ureterorenoscopy. It should be suspected in patients who present with symptoms of side pain, fever, or hematuria following ureterorenoscopic stone treatment. The risk of hospitalization for this specific complication was statistically same in the FURS and RURS groups.

\section{Ethics}

Ethics Committee Approval: This study was approved by the Yüzüncü Yıl University Ethics Committee (approval number: 2015-00/122).

Informed Consent: Consent form was filled out by all participants.

Peer-review: Externally peer-reviewed.

\section{Authorship Contributions}

Surgical and Medical Practices: K.T., M.G., M.E., Concept: K.T., M.G., Design: K.T., M.I.D., Data Collection or Processing: K.T., M.G., M.E., Analysis or Interpretation: K.T., M.I.D., Literature Search: K.T., M.I.D., Writing: K.T.

Conflict of Interest: No conflict of interest was declared by the authors.

Financial Disclosure: The authors declared that this study received no financial support.

\section{References}

1. Isen K. Single-session ureteroscopic pneumatic lithotripsy for the management of bilateral ureteric stones. Int Braz J Urol 2012;38:63-68.

2. Breda A, Ogunyemi O, Leppert JT, Lam JS, Schulam PG. Flexible ureteroscopy and laser lithotripsy for single intrarenal stones $2 \mathrm{~cm}$ or greater--is this the new frontier? J Urol 2008:179:981-984.

3. Aboumarzouk OM, Monga M, Kata SG, Traxer O, Somani BK. Flexible ureteroscopy and laser lithotripsy for stones $>2 \mathrm{~cm}$ : a systematic review and meta-analysis. J Endourol 2012;26:1257-1263.

4. Kuo RL, Aslan P, Fitzgerald KB, Preminger GM. Use of ureteroscopy and holmium:YAG laser in patients with bleeding diatheses. Urology 1998:52:609-613.

5. Bai J, Li C, Wang S, Liu J, Ye Z, Yu X, Xi Q, Ni M, He D. Subcapsular renal haematoma after holmium:yttrium-aluminum-garnet laser ureterolithotripsy. BJU Int 2012;109:1230-1234.

6. Kozminski MA, Kozminski DJ, Roberts WW, Faerber GJ, Hollingsworth JM, Wolf JS Jr. Symptomatic subcapsular and perinephric hematoma following ureteroscopic lithotripsy for renal calculi. J Endourol 2015;29:277-282.

7. Bansal U, Sawant A, Dhabalia J. Subcapsular renal hematoma after ureterorenoscopy: An unknown complication of a known procedure. Urology Ann 2010;2:119-121.

8. Nuttall MC, Abbaraju J, Dickinson IK, Sriprasad S. A review of studies reporting on complications of upper urinary tract stone ablation using the holmium:YAG laser . Br J Med Surg Urol 2010;3:151-156.

9. Meng $H$, Chen $S$, Chen $G$, Tan $F$, Wang $C$, Shen B. Renal subcapsular hemorrhage complicating ureterolithotripsy: an unknown complication of a known day-to-day procedure. Urol Int 2013;91:335-339.

10. Chiu PK, Chan CK, Ma WK, To KC, Cheung FK, Yiu MK. Subcapsular hematoma after ureteroscopy and laser lithotripsy. J Endourol 2013;27:1115-1119.

11. Rehman J, Monga M, Landman J, Lee DI, Felfela T, Conradie MC, Srinivas R, Sundaram CP, Clayman RV. Characterization of intrapelvic pressure during ureteropyeloscopy with ureteral access sheaths. Urology 2003;61:713-718.

12. Kendall AR, Senay BA, Coll ME. Spontaneous subcapsular renal hematoma: diagnosis and management. J Urol 1988;139:246-250.

13. Morgentaler A, Belville JS, Tumeh SS, Richie JP, Loughlin KR. Rational approach to evaluation and management of spontaneous perirenal hemorrhage. Surg Gynecol Obstet 1990;170:121-125.

14. Koo V, Duggan B, Lennon G. Spontaneous rupture of kidney with peri-renal haematoma: a conservative approach. Ulster Med J 2004;73:53-56.

15. Srinivasan V, Turner AG, Blackford HN. Massive intraperitoneal hemorrhage associated with renal pathology. J Urol 1994;151:980-981.

16. Xu L, Li G. Life-threatening subcapsular renal hematoma after flexible ureteroscopic laser lithotripsy: treatment with superselective renal arterial embolization. Urolithiasis 2013;41:449-451. 